\title{
Introducing the Hospitality Roundtable on Legal Issues
}

by DAVID S. SHERWYN

$\mathrm{I}$ am pleased to present this issue's section on issues connected to employment law. The section comprises three articles, two of which stem directly from a roundtable held at the Cornell University School of Hotel Administration.

In spring 2003, the Center for Hospitality Research sponsored the second annual Hospitality Industry Labor and Employment Law Roundtable. The roundtable is exciting for the following three reasons: (1) the participants, (2) the format, and (3) the content. The participants in 2003 consisted of in-house counsel from major industry employers, private practice lawyers from topflight law firms, and professors from leading law, industrial and labor relations, and hotel schools. Specifically, in 2003, our in-house counsel included Zev Eigen, from Fox Entertainment; Alyse Jacobson, from Starwood Hotels \& Resorts Worldwide Inc.; Jonathon Perez, from Darden Restaurants; Mike Smith, from Omni Hotels; and Susan Sandidge, from Brinker International. The private practice lawyers included Joe Baumgarten, from Proskauer, Rose; Ilene Berman, from Fisher \& Philips; Gregg Gilman, from Davis \& Gilbert; Howard Lavin, from Strook \& Strook \& Lavan; Paul Wagner, from Stokes \& Murphy; Joe Yastrow, from Laner, Muchin; and Jim Zuehl, from Franczek, Sullivan. The professors included Cindy Estlund, from Columbia Law School; Sam Estreicher, from New York University Law School; Michael Gold, from Cornell's School of Industrial and Labor Relations; Michael Heise, from Cornell Law School; and Michael Yelnosky, from Roger Williams Law School. Students from the Hotel School's course Employment Discrimination/UnionManagement Relations joined the distinguished panelists at each of the sessions.

The format of the roundtable is unusual and productive. Most conferences consist of long presentations followed by short discussion; we do the opposite. We begin with presentations that do not exceed ten minutes. Two "discussants" follow the presentation with comments that cannot exceed five minutes. The remaining hour and fifteen minutes of each session consists of a free-flowing discussion among the roundtable participants and students. Participants dis- 
cuss, argue, agree, disagree, think, rethink, and often laugh as we try to get a handle on the pressing labor and employment issues affecting our industry.

The final component of the roundtable is the content. In 2003, we had five sessions: (1) sexual harassment after Oncale, Holman, and Rene; (2) the effect of the Supreme Court's "mixed motive" decision in Costa; (3) arbitration versus mediation; (4) livable wage and other union issues; and (5) hot topics. Hot topics, our final session each year, arose when Scott Cordes, formally of Accor, stated that he had a number of questions for the participants but "none that were worth an hour." He asked, and we agreed, that this was a great way to conclude the event. We have done it the past two years and will again this year. Three of the other topics form the basis for articles in this issue of the Cornell Quarterly.

The discussion on sexual harassment prompted Gregg Gilman, Paul Wagner, and me to write an article that extols the need for education in preventing sexual harassment, provides an in-depth discussion of where the law is now, and offers employers strategies on how to comply. The mixed motive session resulted in Joe Baumgarten, Paul Wagner, and me writing an article that contends that because of the Costa decision, discrimination lawsuits may become much more expensive to settle and almost impossible for employers to win. This session also con-

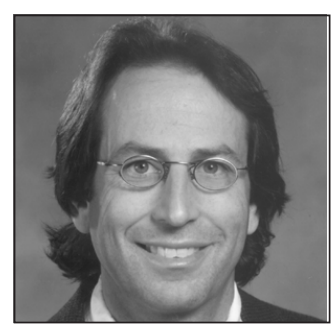

vinced Proskauer to sponsor an ambitious research project to see whether this is, in fact, the case.

The third article of this section, by Satish Deshpande and Christina Stamper, of Western Michigan University, is about the antecedents of successful union drives in the hospitality industry. Although they were not at the roundtable, their topic was one that was discussed in depth. Adding this article to this section provides an interesting complement to the two articles coming directly from the roundtable participants.

The 2004 Roundtable will be held on May 16 and 17. Almost all of the 2002 and 2003 participants will be back. In addition, I am thrilled that Leslie New (who, in addition to graduating from the Hotel School in 1998 and Cornell Law School in 2003, was the teaching assistant for two law courses at the Hotel School) will move from student to participant as she represents her law firm, Littler, Mendelsohn. In addition, I hope that Leslie will be joined by Seyfarth Shaw's Amy Chang and Gibson Dunn's Jenn Walwyn. Both Amy and Jenn graduated from the Hotel School in 2000 and from law school in 2003.

The roundtable is an exciting way for faculty, students, and practicing lawyers to interact and learn from each other. In addition, it provides an impetus for academic work in the Cornell Quarterly, as well as other venues. If you are interested in the roundtable, please contact me at dss18@cornell.edu.

David S. Sherwyn, J.D., is an associate professor of law at the Cornell Hotel School (dss18@ cornell.edu). 